\title{
Impact of insulin antibodies on insulin aspart pharmacokinetics and pharmacodynamics after 12-week treatment with multiple daily injections of biphasic insulin aspart 30 in patients with type 1 diabetes
}

\author{
J-W Chen ${ }^{1,2}$, J Frystyk ${ }^{1}$, T Lauritzen ${ }^{2}$ and J S Christiansen ${ }^{1}$ \\ ${ }^{1}$ Department of Endocrinology and Diabetes and Medical Research Laboratories, Aarhus University Hospital, Norrebrogade 44, DK-8000, \\ Aarhus C, Denmark and ${ }^{2}$ Department of General Practice, Aarhus University, Aarhus, Denmark \\ (Correspondence should be addressed to J-W Chen; Email: wen@iekf.au.dk)
}

\begin{abstract}
Objective: This study aimed to evaluate the impact of insulin antibodies on insulin aspart pharmacokinetics and pharmacodynamics after 12-week multiple daily injections of biphasic insulin aspart 30 (30\% fast-acting and $70 \%$ protamine-crystallised insulin aspart, BIAsp30) in patients with type 1 diabetes.

Methods: Twenty-three patients ( 8 women, 15 men) aged 44.8 (20.6-62.5) years (median and range) with diabetes duration of 19.5 (1.6-44.6) years and haemoglobin $(\mathrm{Hb}) \mathrm{A}_{1 \mathrm{c}}$ of $9.2 \%(8.1-12.3 \%)$ participated in the study, which consisted of 12-week treatment with multiple injections of BIAsp30. At the end of the treatment period, all patients attended two 24-h profile days 1 week apart for pharmacokinetic and pharmacodynamic assessments. $\mathrm{HbA}_{1 \mathrm{C}}$ and insulin antibodies were also determined.

Results: Patients were stratified into two groups depending on whether the level of insulin binding to insulin antibodies was below or above 75\% (moderate vs high (\%, median and range): 62 (15-74) vs $80(75-89))$. High levels of insulin antibodies resulted in about threefold increase in $\mathrm{AUC}_{(0-24 \mathrm{~h})}($ the area under the concentration-time curve during $24 \mathrm{~h}$ ) for total insulin aspart (analysis of variance, $P<0.05)$. The differences in free insulin aspart pharmacokinetics, insulin pharmacodynamics and $\mathrm{HbA}_{1 \mathrm{C}}$ were not statistically significant between patients with different levels of insulin antibodies. Total daily insulin dosage was significantly lower in patients with high than moderate levels of insulin antibodies.

Conclusions: In type 1 diabetic patients, high levels of circulating insulin antibodies result in elevated total, but not free, insulin aspart profiles. Consistent with the finding of similar insulin pharmacodynamics, the long-term glycaemic control is not significantly different between patients with different levels of insulin antibodies.
\end{abstract}

European Journal of Endocrinology 153 907-913

\section{Introduction}

The production of polyclonal IgG antibodies in response to administration of exogenous insulin (including human insulin) has aroused academic as well as clinical interest $(1,2)$, because these antibodies may diminish (or neutralise) the action of insulin - a condition called immunological insulin resistance (3), and induce lipoatrophy at the injection site (4). Furthermore, it has been speculated that antibodies against insulin will serve as carrier proteins, prolonging the duration of action of circulating insulin, and consequently result in profound alterations in insulin pharmacokinetics and pharmacodynamics (5-8).
Insulin aspart is an insulin analogue designed by protein engineering, in which aspartic acid replaces proline at position B28 of the human insulin molecule (9). With this substitution, a more brisk absorption profile than with soluble human insulin has been achieved $(10,11)$. However, the treatment with insulin analogues raises some new concerns. Thus, a previous study suggested that insulin aspart possessed the same immunogenicity as porcine insulin because both insulins differ from native human insulin by one amino acid located at the C-terminal of the B-chain of the insulin molecule (12). This may explain the observation that administration of insulin aspart is associated with increased insulin-antibody titers (13). 
However, the influence of such antibodies on insulin aspart pharmacokinetics and pharmacodynamics has not yet been evaluated.

The present study aimed to compare differences in insulin pharmacokinetics and pharmacodynamics in type 1 diabetic patients with moderate and high levels of insulin antibodies respectively after 12 weeks of multiple daily injections of biphasic insulin aspart 30 (30\% fasting-acting and $70 \%$ protamine-crystallised insulin aspart, BIAsp30), and to evaluate the relationship between the presence of insulin antibodies and longterm glycaemic control.

\section{Patients and methods}

The trial protocol was approved by the Danish Medicines Agency and the local ethics committee. The trial was conducted in accordance with Good Clinical Practice (GCP), and monitored by the GCP unit of Aarhus University Hospital. Written, informed consent was obtained from all patients before the trial.

\section{Patients}

The present study was part of a larger randomised, openlabel, two-period, crossover trial comparing the effects of 12 weeks of multiple daily injections of BIAsp30 (NovoMix ${ }^{\circledR} 30$ FlexPen ${ }^{\circledR}$; Novo Nordisk A/S, Bagsvaerd, Denmark) to basal-bolus human insulin administration (Actrapid ${ }^{\circledR}$ Pen and Insulatard ${ }^{\circledR}$ FlexPen ${ }^{\circledR}$ respectively; Novo Nordisk A/S) on long-term glycaemic control. The present paper included data obtained during treatment with BIAsp30 only, involving 23 type 1 diabetic patients ( 8 women, $15 \mathrm{men}$ ), who were previously treated with basal-bolus human insulin administration (three injections of soluble human insulin at mealtime in addition to bedtime NPH insulin). They were aged $44.8(20.6-62.5)$ years (median and range) with diabetes duration of $19.5(1.6-44.6)$ years and a haemoglobin $(\mathrm{Hb}) \mathrm{A}_{1 \mathrm{C}}$ of $9.2 \%(8.1-12.3 \%)$.

At the end of the treatment period, patients attended two 24 -h profile days 1 week apart. On all profile days, patients reported to the clinical research unit at $0730 \mathrm{~h}$ after overnight fast. After the first sample at approximately $0745 \mathrm{~h}$, patients were administered the trial drugs after blood sampling at 0800, 1300 and $1800 \mathrm{~h}$. Within $5 \mathrm{~min}$ after insulin administration, meals were served. The amount and pattern of meals and snacks during the profile days were as close as possible to the patients' daily life, and were unchanged on the profile days. After each main meal, blood samples were drawn every $30 \mathrm{~min}$ for $2 \mathrm{~h}$, followed by hourly sampling until the next meal or $0200 \mathrm{~h}$, and then two-hourly until the end of the 24-h profile day. Insulin dosages remained unchanged from the day before the first profile day to the end of the second 24-h profile day. BIAsp30 was injected immediately before the meal.

\section{Free and total insulin aspart measurements in serum}

Peptides Monoclonal antibodies to human insulin (HUI-081) and insulin aspart (X14-6F34) and insulin aspart standards were kindly provided by L Andersen (Department of Immunochemistry, Novo Nordisk A/S) (14). HUI-081 was employed as coating antibody ( $3 \mathrm{mg} / \mathrm{l})$. X14-6F34, labelled with europium according to the manufacturer's instructions (PerkinElmer Life Sciences, Turku, Finland), served as detecting antibody.

Assay buffers Coating was performed with 1 M PBS, $\mathrm{pH}$ 8.4. Elution buffer was made of either $2 \mathrm{mM}$ phosphate, $\mathrm{pH} 8.0$ (buffer A) or $0.2 \mathrm{M}$ acetic acid (buffer B), containing $0.15 \%$ o $(\mathrm{w} / \mathrm{v})$ human serum albumin (HSA), $0.45 \%$ ( w/v) NaCl, 0.1\%o (v/v) Tween 20 and $0.1 \%$ ( $/ \mathrm{v})$ DTPA. The reconstitution buffer was made of $20 \mathrm{mM}$ phosphate, $\mathrm{pH} 8.0$ (buffer C) or $0.2 \mathrm{M}$ Tris$\mathrm{HCl}, \mathrm{pH} 8.0$ (buffer D), consisting of $2 \%$ (w/v) HSA, $5 \%$ (w/v) NaCl, 2\%o (v/v) Tween 20 and 2\%o (v/v) DTPA.

Column preparation Sephadex G50 Fine (Amersham Biosciences AB, Uppsala, Sweden) gel-filtration medium was swollen overnight at room temperature in buffer $\mathrm{A}$ (neutral column) or buffer B (acid column). About $6 \mathrm{ml}$ gel was packed in Fisher Screening Column $(1 \times 6 \mathrm{~cm}$, diameter $\times$ length; cat. no. 1138750 , Fisher Scientific, Pittsburgh, PA, USA).

GeI separation procedure In a pilot study, ${ }^{125}$ I-human insulin (7000 counts/min) (Novo Nordisk A/S) was incubated overnight at $5^{\circ} \mathrm{C}$ with buffer with or without an excess of human immunoglobulin (Octapharma, Holte, Denmark). Next day, $120 \mu \mathrm{l}$ of the mixtures $\left({ }^{125} \mathrm{I}\right.$-insulin $\left.\mathrm{IgG}\right)$ were applied to the neutral column, which was eluted with buffer A $(150 \mu \mathrm{l} /$ fraction). In another experiment, $125 \mu \mathrm{l}^{125} \mathrm{I}$-insulin IgG were incubated with $30 \mu \mathrm{l} 1 \mathrm{M} \mathrm{HCl}$ at room temperature for $2 \mathrm{~h}$, after which $120 \mu \mathrm{l}$ were added to the acid column and eluted with buffer B (150 $\mu$ l/fraction). The radioactivity of each fraction collected was counted. The results are presented in Fig. 1A. Our pilot studies showed that in the neutral column, the complexes of ${ }^{125}$ I-insulin and human IgG eluted in fractions $10-15$, and ${ }^{125}$ I-insulin eluted in fractions $16-$ 30. In the acid column, unbound ${ }^{125}$ I-insulin appeared in fractions $18-33$.

Furthermore, serum samples were taken from three fasted patients who participated in the present study and had low $(6 \%)$, moderate $(47 \%)$ and high $(84 \%)$ antibody-binding capacity (coprecipitation) respectively. Serum samples were incubated with ${ }^{125}$ I-human insulin (12 000, 13000 and 9000 counts/min respectively) at room temperature for $2 \mathrm{~h}$. After incubation, $120 \mu \mathrm{l}$ were applied to the neutral column, which was eluted as described above. The results are shown in Fig. 1B. 

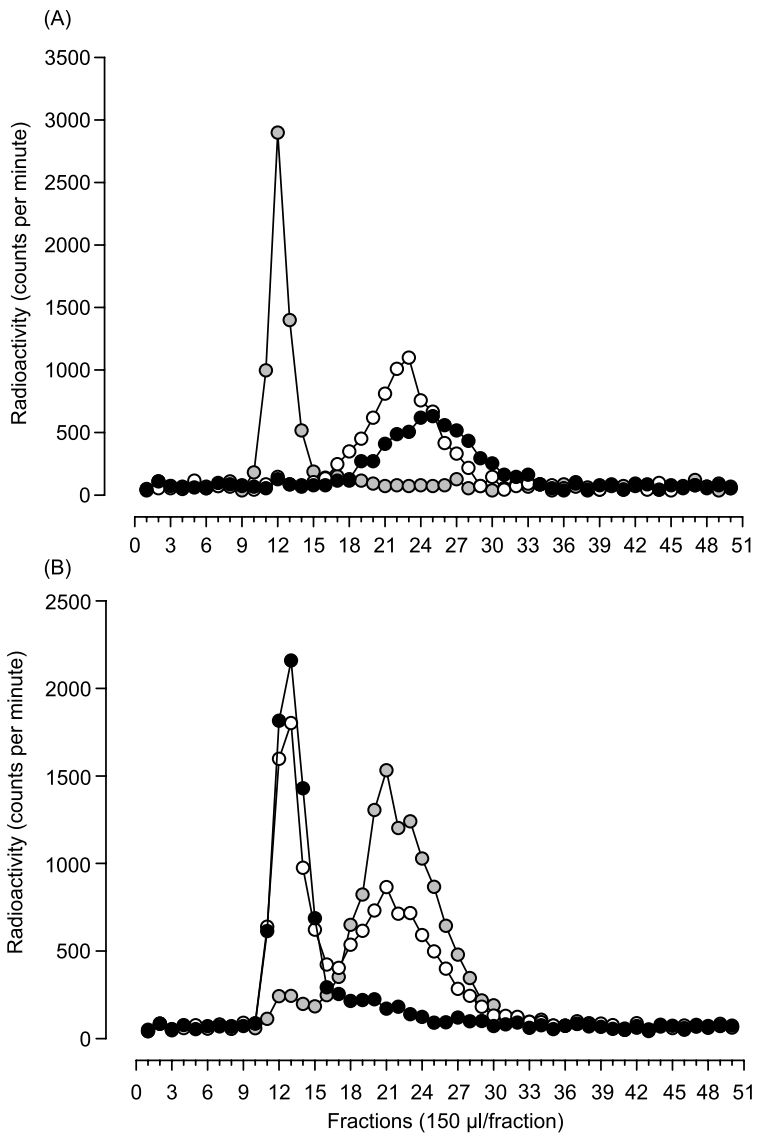

Figure 1 Size exclusion gel chromatography for free and total insulin aspart determination. (A) Applying complex ${ }^{125} \mathrm{I}$-human insulin and IgG to neutral column (๑); applying ${ }^{125}$ I-human insulin to neutral column (O); after acidification, applying complex ${ }^{125}$ Ihuman insulin-human IgG to acid column (@); (B) Sera with low antibody-binding capacity $(\bigcirc)$; sera with moderate antibody-binding capacity $(\bigcirc)$; sera with high antibody-binding capacity $(\bullet)$.

The radioactivities eluted in fractions 11-16 were 10\% of total counts for low-binding sera, but $46 \%$ and $82 \%$ for moderately and high-binding sera respectively.

Thus, the $6 \mathrm{ml}$ columns were able to separate bound from free insulin at acidic as well neutral conditions. However, due to the volume being collected in fractions 16-33 (about $2.6 \mathrm{ml}$ ), lyophilisation was needed to improve assay sensitivity. Accordingly, after lyophilisation, buffers $\mathrm{C}$ and $\mathrm{D}(300 \mu \mathrm{l} /$ sample $)$ were added for free and total insulin aspart determinations respectively. Afterward, insulin aspart was measured by a sandwich assay as described by Andersen et al. (14), except that the detecting antibody was europium labelled (timeresolved immunofluorometric assay (TR-IMFA)).

For free insulin aspart (neutral column), the recovery rate was $111 \pm 10 \%$ at $32.25 \mathrm{pmol} / \mathrm{l}$ and $115 \pm 8 \%$ at $500 \mathrm{pmol} / \mathrm{l}$. The within- and between-assay coefficient of variations (CV) both averaged 5.4\% (derived from 40 assessments on 8 consecutive days). The recovery of total insulin aspart (acid column) was $95 \pm 13 \%$ in six patients with type 1 diabetes, and $96 \pm 9 \%$ in six normal healthy subjects. The within- and betweenassay CV for total insulin aspart assay averaged $4.5 \%$ and $7.6 \%$ respectively. Serum insulin aspart concentrations below the detection limit $(15.625 \mathrm{pmol} / \mathrm{l})$ were set to $7.8 \mathrm{pmol} / \mathrm{l}$.

\section{Other measurements}

Insulin antibodies were determined only at the end of treatment period by the method of Desbuquois et al. (15), and expressed as percentage of bound ${ }^{125}$ I-insulin. In our laboratory, the mean antibody-binding capacity (coprecipitation) in serum from normal healthy subjects was $4.8 \pm 0.2 \%$.

$\mathrm{HbA}_{1 \mathrm{C}}$ was measured at the end of each 12-week treatment period by high-performance liquid chromatography (HPLC) (normal range: 5.1-6.2\%). Profile day plasma glucose concentrations were measured by the glucose oxidase method.

\section{Pharmacodynamic and pharmacokinetic assessments}

The area under the plasma glucose or insulin concentration-time curve (AUC) was calculated by the trapezoidal rule, and stratified into four sections $\left(\mathrm{AUC}_{\text {breakfast }}\left(\mathrm{O}_{-}\right.\right.$ $\left.5 \mathrm{~h}), \mathrm{AUC}_{\text {lunch }(0-5 \mathrm{~h})}, \mathrm{AUC}_{\text {dinner }(0-4 \mathrm{~h})}, \mathrm{AUC}_{\text {dinner(}(4-14 \mathrm{~h})}\right)$. The day-to-day variation in insulin pharmacokinetics and pharmacodynamics was expressed as the $\mathrm{CV}$, which was calculated with corresponding parameters on two 24-h profile days.

\section{Statistical analyses}

After logarithmic transformation (ln), differences in total daily insulin dosage and AUC between patients with different levels of insulin antibodies were analysed by ANOVA (analysis of variance). The Mann-Whitney test was employed to compare the difference in $\mathrm{HbA}_{1 \mathrm{C}}$, day-to-day variations in insulin pharmacokinetics and pharmacodynamics. The corresponding values on two 24-h profile days were averaged to compare differences between patients. Additionally, a linear regression model with total AUC $\left(\mathrm{AUC}_{(0-24 \mathrm{~h})}\right)$ for plasma glucose, as well as total and free insulin aspart respectively as dependent variables and the level of insulin antibodies as independent variables, was chosen to evaluate the relationships between these parameters.

Data were analysed by SPSS for Windows, Version 11 (SPSS, Chicago, IL, USA). All statistical analyses were performed with a significance level of 5\%.

\section{Results}

The median (range) level of insulin antibodies was 75\% (15-89\%) after 12-week treatment with multiple daily injections of BIAsp30. 
The patients were stratified into two groups depending on whether the level of insulin antibodies was below or above $75 \%$ after treatment with multiple injections of BIAsp30. In patients with low to moderate insulin binding $(n=11)$, the level of insulin antibodies was $62 \%(15-74 \%)$, but it was $80 \%(75-89 \%)$ in patients with high insulin binding $(n=12)$.

\section{Pharmacokinetics and pharmacodynamics}

The total insulin aspart profiles were significantly higher in patients with high versus low to moderate levels of insulin antibodies (Fig. 2A). High levels of insulin antibodies were associated with an approximately threefold increase in $\mathrm{AUC}_{(0-24 \mathrm{~h})}$ for total insulin aspart $(P<0.05)$ (Table 1$)$. Furthermore, total insulin aspart profiles at different time points of the profile days were significantly elevated by $250-280 \%$ in patients with high versus low to moderate levels of insulin antibodies (Table 1).

Free insulin aspart and glucose profiles were superimposable in patients with low to moderate and high levels of insulin antibodies (Fig. 2B and C respectively). $\mathrm{AUC}_{(0-24 \mathrm{~h})}$ for free insulin aspart and glucose were not significantly different between patients with different levels of insulin antibodies (Table 1).

The day-to-day variations in insulin pharmacokinetics and pharmacodynamics $\left(\mathrm{AUC}_{(0-24 \mathrm{~h})}\right)$ were not significantly different between the two groups (low to moderate vs high (\%, median and interquartile): $6 \%$ $(2-21 \%)$ vs $6 \%(1-26 \%)$ for total insulin aspart; $13 \%$ $(8-20 \%)$ vs $8 \%(4-21 \%)$ for free insulin aspart; $10 \%$ $(5-17 \%)$ vs $12 \%(8-32 \%)$ for blood glucose) (NS).

$\mathrm{AUC}_{(0-24 \mathrm{~h})}$ for total insulin aspart was positively but weakly correlated with the level of insulin antibodies $\left(r^{2}=0.19, P=0.04\right)$. Neither free insulin aspart $\left(r^{2}=0.026\right)$ nor glucose concentrations $\left(r^{2}=0.059\right)$ were independently predicted by the level of insulin antibodies (NS).

\section{Long-term glycaemic control and insulin dosage}

There was no significant difference in $\mathrm{HbA}_{1 \mathrm{C}}$ between patients with low to moderate and high levels of insulin antibodies (low to moderate vs high (\%, median and range): $8.3 \%(6.7-9.7 \%)$ vs $8.3 \%(7.3-9.8 \%)(\mathrm{NS})$.

The total daily insulin dosage was significantly lower in patients with high compared with low to moderate levels of insulin antibodies (low to moderate vs high (IU/24 h, geometric mean and range): 59 (44-82) vs $43(24-106)(P=0.039)$.

\section{Discussion}

This is the first study to show that increased insulin antibody-binding capacity is associated with signifi- cantly elevated total, but not free, insulin aspart profiles after 12-week treatment with multiple daily injections of BIAsp30. However, no profound influence of insulin antibodies on insulin pharmacodynamics was observed, and consequently the long-term glycaemic control as measured by $\mathrm{HbA}_{1 \mathrm{C}}$ was not significantly different between patients with different levels of insu-
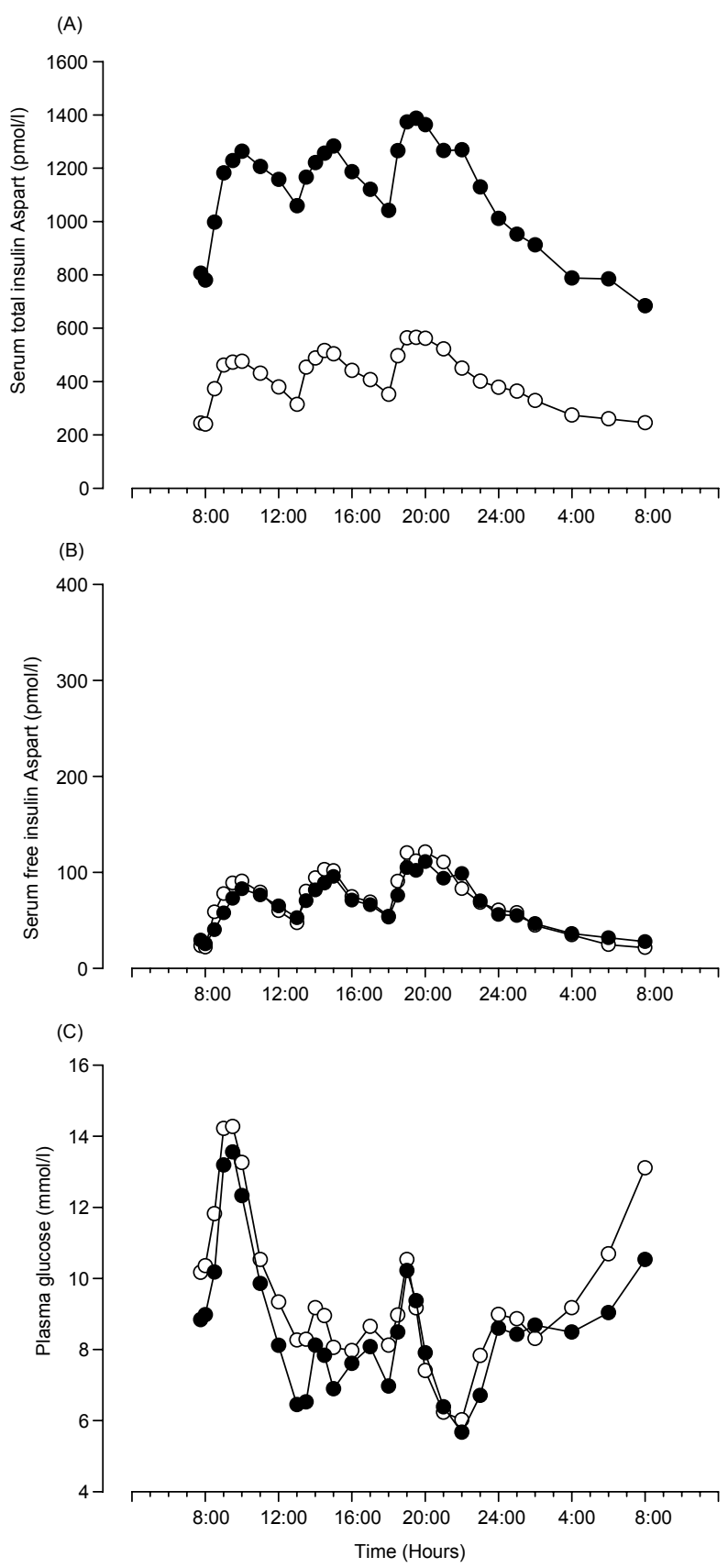

Figure 2 The influence of insulin antibody on total insulin aspart $(A)$, free insulin aspart (B) and blood glucose (C) in patients with high $(\bullet)$ or low to moderate $(O)$ levels of insulin antibodies. The results are presented as geometric mean. 
Table 1 Differences in insulin pharmacodynamics and pharmacokinetics between patients with low to moderate and high insulinantibody binding*.

\begin{tabular}{|c|c|c|c|c|c|}
\hline & \multirow{2}{*}{$\frac{\text { Low to moderate }}{\text { Mean }}$} & \multirow{2}{*}{$\frac{\text { High }}{\text { Mean }}$} & \multicolumn{3}{|c|}{ High/moderate } \\
\hline & & & Ratio & $95 \% \mathrm{Cl}$ & $P$ value \\
\hline \multicolumn{6}{|l|}{ Total insulin aspart pharmacokinetics } \\
\hline $\mathrm{AUC}_{(0-24 \mathrm{~h})}(\mathrm{pmol} \times \mathrm{h} / \mathrm{l})$ & 9685.9 & 25478.0 & 2.63 & $(1.09,6.32)$ & 0.03 \\
\hline$A \cup C_{\text {breakfast }(0-5 \mathrm{~h})}(\mathrm{pmol} \times \mathrm{h} / \mathrm{l})$ & 2115.1 & 5997.0 & 2.84 & $(1.17,6.84)$ & 0.02 \\
\hline $\mathrm{AUC}_{\text {lunch }(0-5 \mathrm{~h})}(\mathrm{pmol} \times \mathrm{h} / \mathrm{l})$ & 2220.7 & 5885.2 & 2.65 & $(1,12,6.27)$ & 0.03 \\
\hline$A \cup C_{\text {dinner(0-4h) }}(\mathrm{pmol} \times \mathrm{h} / \mathrm{l})$ & 2074.5 & 5222.2 & 2.51 & $(1.15,5.50)$ & 0.02 \\
\hline$A \cup C_{\text {dinner(4-14h) }}(\mathrm{pmol} \times \mathrm{h} / \mathrm{l})$ & 3210.0 & 8565.7 & 2.67 & $(1.01,7.08)$ & 0.05 \\
\hline \multicolumn{6}{|l|}{ Free insulin aspart pharmacokinetics } \\
\hline $\mathrm{AUC}_{(0-24 \mathrm{~h})}(\mathrm{pmol} \times \mathrm{h} / \mathrm{l})$ & 1638.9 & 1565.8 & 0.96 & $(0.61,1.51)$ & 0.84 \\
\hline$A \cup C_{\text {breakfast }(0-5 \mathrm{~h})}(\mathrm{pmol} \times \mathrm{h} / \mathrm{l})$ & 359.9 & 334.0 & 0.93 & $(0,55,1.57)$ & 0.77 \\
\hline$A \cup C_{\text {lunch }(0-5 h)}(\mathrm{pmol} \times \mathrm{h} / \mathrm{l})$ & 400.7 & 370.6 & 0.92 & $(0.56,1.54)$ & 0.75 \\
\hline$A \cup C_{\text {dinner }(0-4 h)}(\mathrm{pmol} \times \mathrm{h} / \mathrm{l})$ & 420.0 & 402.8 & 0.96 & $(0.65,1.42)$ & 0.83 \\
\hline$A \cup C_{\text {dinner }(4-1 \mathrm{~h})}(\mathrm{pmol} \times \mathrm{h} / \mathrm{l})$ & 440.8 & 449.5 & 1.02 & $(0.60,1.74)$ & 0.94 \\
\hline \multicolumn{6}{|l|}{ Insulin aspart pharmacodynamics } \\
\hline $\mathrm{AUC}_{(0-24 \mathrm{~h})}(\mathrm{mmol} \times \mathrm{h} / \mathrm{l})$ & 232.2 & 206.5 & 0.89 & $(0.78,1.01)$ & 0.06 \\
\hline$A \cup C_{\text {breakfast }(0-5 \mathrm{~h})}(\mathrm{mmol} \times \mathrm{h} / \mathrm{l})$ & 59.9 & 54.4 & 0.91 & $(0,77,1.08)$ & 0.26 \\
\hline$A \cup C_{\text {lunch }(0-5 \mathrm{~h})}(\mathrm{mmol} \times \mathrm{h} / \mathrm{l})$ & 42.5 & 37.6 & 0.89 & $(0.68,1.15)$ & 0.35 \\
\hline$A \cup C_{\text {dinner }(0-4 \mathrm{~h})}(\mathrm{mmol} \times \mathrm{h} / \mathrm{l})$ & 31.3 & 30.8 & 0.98 & $(0.77,1.25)$ & 0.89 \\
\hline$A \cup C_{\text {dinner }(4-14 \mathrm{~h}}(\mathrm{mmol} \times \mathrm{h} / \mathrm{l})$ & 95.0 & 82.2 & 0.86 & $(0.68,1.09)$ & 0.21 \\
\hline
\end{tabular}

* Results are expressed as geometric means drawn from ANOVA. The mean ratio between patients with different levels of insulin-antibodies and $95 \% \mathrm{CI}$ for the ratio are also shown.

lin antibodies. Our observations agree with earlier studies (16-18), and together they suggest that total insulin profiles may not appropriately explain the corresponding changes in insulin pharmacodynamic profiles, when patients with different levels of insulin antibodies are compared.

In contrast to our findings, some previous studies have reported that after subcutaneous injection of short- or intermediate-acting insulin, plasma free insulin concentrations are lower in patients with insulin antibodies than in those without (5-8). It has been suspected that binding of insulin by circulating antibodies or an impaired insulin absorption due to the local binding of insulin by antibodies at the subcutaneous injection site might be the explanation for the lower plasma free insulin profiles observed in the patients with high levels of insulin antibodies (19, 20). However, the latter hypothesis remains to be proven; in fact, de Meijer et al. failed to demonstrate any significant difference in absorption rate of ${ }^{125} \mathrm{I}-$ labelled soluble human insulin between patients with and without antibodies (16). The reason for this discrepancy is unknown, but it may relate to the inclusion of different patient groups as well as a different assay for insulin antibodies and for total and free insulin (21).

The absorption of insulin from the subcutaneous injection site is characterised by huge spontaneous intra- and interindividual variations (up to 50\%) (22, 23). Such a variability in insulin pharmacokinetics might result in a labile glycaemic control (23). It has been suggested that insulin antibodies may act as a buffer, binding circulating insulin and releasing it slowly, thereby stabilising glycaemic control $(24,25)$.
Accordingly, it was anticipated that patients with elevated levels of insulin antibodies would have a smaller day-to-day variation in insulin pharmacokinetics. In the present study, however, within-patient variations in insulin aspart pharmacokinetics and pharmacodynamics were similar in patients with low to moderate and high levels of insulin antibodies. This finding agrees with a previous study using purified, shortacting porcine insulin (17). Our results suggest that the formation of insulin antibodies may not have significant impact on insulin aspart pharmacokinetics and pharmacodynamics after 12-week treatment with multiple daily injections of BIAsp30, where the levels of insulin antibodies are considered to be at the maximum (13).

In 1944, Lowell first reported that the presence of insulin antibodies might neutralise the action of exogenous insulin (26). Since then, there has been the debate on the clinical importance of insulin antibodies (25). Unfortunately, the conclusions are still ambiguous. We believe that some influence of insulin antibodies cannot be completely excluded during multiple injections of BIAsp30. First of all, it is likely that the circulating insulin antibodies induced by exogenous insulin administration act as binding proteins, prolonging the duration of action of insulin in the circulation $(5,7$, 18, 19). Accordingly, lower insulin requirement would be expected in patients with high levels of insulin antibodies (27). Indeed, our results showed that the total daily insulin dosage was significantly lower in patients with high than moderate levels of insulin antibodies, although these patients had almost similar glycaemic control. However, the opposite conclusion has been 
reached by other researchers $(6,13,28)$. Nevertheless, due to the buffering effects of insulin antibodies, various regimens for insulin dosage titration may be required for patients with different levels of insulin antibodies; that is, in patients with higher insulin antibodies-binding capacity, a regimen with more aggressive dose increment (decrement) but longer titration interval might be more appropriate, and vice versa. However, such a hypothesis should be evaluated in a clinical trial.

Secondly, due to an increased (10-fold) stimulatory cross-reaction with the insulin-like growth factor-I (IGF-I) receptor (29), the treatment with another insulin analogue, B10Asp, has caused some concern (30). Recently, we have studied the capacity of insulin aspart to cross-react with the IGF-I receptor in vitro (31). It appeared that at a level of $\sim 1700 \mathrm{pmol} / \mathrm{l}$ (similar to the mean level of total insulin aspart observed in patients with high levels of insulin antibodies in the present study), the signal from insulin aspart was equivalent to $13 \mathrm{pmol} / \mathrm{l}$ IGF-I. This crossreactivity $(0.7 \%)$ was similar to that of short-acting human insulin (0.8\%); therefore, we do not believe that treatment with insulin aspart should raise any safety concern - at least in the context of IGF-I receptor activation. However, we acknowledge that type 1 diabetic patients are at increased risk of cancer as compared with non-diabetic population (32), and it is still unknown whether lifelong treatment with insulin aspart will lead to an elevated IGF-I-like bioactivity and subsequent mitogenic potency, especially in the subgroup of patients who have high levels of insulin antibodies.

In conclusion, in type 1 diabetic patients, high levels of circulating insulin antibodies result in elevated total, but not free, insulin aspart profiles. However, the insulin aspart pharmacodynamic profiles are independent of the levels of insulin antibodies; accordingly, the long-term glycaemic control is not significantly different between patients with moderate and high levels of insulin antibodies.

\section{Acknowledgements}

We thank Professor Hans Øskov for his wonderful methodological suggestions during the study. The skilful assistance of Ms Ulla Sigsgaard, Ms Birtha Hansen, Ms Joan Hansen, Ms Inga Bisgaard and Ms Annette Mengel is also highly appreciated.

\section{References}

1 Greenbaum CJ \& Palmer JP. Insulin antibodies and insulin autoantibodies. Diabetic Medicine 1991 8 97-105.

2 van Haeften TW. Clinical significance of insulin antibodies in insulin-treated diabetic patients. Diabetes Care 198912 641-648.

3 Shipp JC, Cunningham RM, Russell JW \& Marble A. Insulin resistance: clinical features, natural course and effects of adrenal steroid treatment. Medicine (Baltimore) 196544 165-186.
4 Reeves WG, Allen BR \& Tattersall RB. Insulin-induced lipoatrophy: evidence for an immune pathogenesis. British Medical Journal $19802801500-1503$.

5 Gray RS, Cowan P, Di Mario U, Elton RA, Clarke BF \& Duncan LJ. Influence of insulin antibodies on pharmacokinetics and bioavailability of recombinant human and highly purified beef insulins in insulin dependent diabetics. British Medical Journal (Clinical Research Edition) 1985290 1687-1691.

6 Peters A, Klose O, Hefty R, Keck F \& Kerner W. The influence of insulin antibodies on the pharmacokinetics of NPH insulin in patients with type 1 diabetes treated with human insulin. Diabetic Medicine 199512 925-930.

7 van Haeften TW, Bolli GB, Dimitriadis GD, Gottesman IS, Horwitz DL \& Gerich JE. Effect of insulin antibodies and their kinetic characteristics on plasma free insulin dynamics in patients with diabetes mellitus. Metabolism 198635 649-656.

8 van Haeften TW, Heiling VJ \& Gerich JE. Adverse effects of insulin antibodies on postprandial plasma glucose and insulin profiles in diabetic patients without immune insulin resistance. Implications for intensive insulin regimens. Diabetes 198736 305-309.

9 Brange J, Ribel U, Hansen JF, Dodson G, Hansen MT, Havelund S, Melberg SG, Norris F, Norris K \& Snel L. Monomeric insulins obtained by protein engineering and their medical implications. Nature 1988333 679-682.

10 Home PD, Barriocanal L \& Lindholm A. Comparative pharmacokinetics and pharmacodynamics of the novel rapid-acting insulin analogue, insulin aspart, in healthy volunteers. European Journal of Clinical Pharmacology 199955 199-203.

11 Kang S, Brange J, Burch A, Volund A \& Owens DR. Subcutaneous insulin absorption explained by insulin's physicochemical properties. Evidence from absorption studies of soluble human insulin and insulin analogues in humans. Diabetes Care 1991 $14942-948$.

12 Ottesen JL, Nilsson P, Jami J, Weilguny D, Duhrkop M, Bucchini D, Havelund S \& Fogh JM. The potential immunogenicity of human insulin and insulin analogues evaluated in a transgenic mouse model. Diabetologia 199437 1178-1185.

13 Lindholm A, Jensen LB, Home PD, Raskin P, Boehm BO \& Rastam J. Immune responses to insulin aspart and biphasic insulin aspart in people with type 1 and type 2 diabetes. Diabetes Care $200225876-882$.

14 Andersen L, Jorgensen PN, Jensen LB \& Walsh D. A new insulin immunoassay specific for the rapid-acting insulin analog, insulin aspart, suitable for bioavailability, bioequivalence, and pharmacokinetic studies. Clinical Biochemistry 200033 627-633.

15 Desbuquois B \& Aurbach GD. Use of polyethylene glycol to separate free and antibody-bound peptide hormones in radioimmunoassays. Journal of Clinical Endocrinology and Metabolism $197133732-738$.

16 de Meijer PH, Lutterman JA \& van't Laar A. Insulin antibodies do not influence the absorption rate of subcutaneously injected insulin. Diabetic Medicine $19885776-781$.

17 Gardner DF, Wilson HK, Podet EJ, Arakaki RF, Nell LJ, Thomas JW, Crane MM \& Field JB. Prolonged action of regular insulin in diabetic patients: lack of relationship to circulating insulin antibodies. Journal of Clinical Endocrinology and Metabolism 198662 621-627.

18 Waldhausl WK, Bratusch-Marrain P, Kruse V, Jensen I, Nowotny P \& Vierhapper H. Effect of insulin antibodies on insulin pharmacokinetics and glucose utilisation in insulin-dependent diabetic patients. Diabetes 198534 166-173.

19 Francis AJ, Hanning I \& Alberti KG. The influence of insulin antibody levels on the plasma profiles and action of subcutaneously injected human and bovine short acting insulins. Diabetologia 198528 330-334.

20 Walford S. Insulin antibodies - do they matter? Netherlands Journal of Medicine 198528 (Suppl 1) 47-49.

21 Reeves WG. Insulin antibody determination: theoretical and practical considerations. Diabetologia 198324 399-403.

22 Binder C, Lauritzen T, Faber O \& Pramming S. Insulin pharmacokinetics. Diabetes Care $19847188-199$. 
23 Lauritzen T. Pharmacokinetic and clinical aspects of intensified subcutaneous insulin therapy. Danish Medical Bulletin $198532104-118$.

24 Dixon K, Exon PD \& Malins JM. Insulin antibodies and the control of diabetes. Quarterly Journal of Medicine $1975 \mathbf{4 4} 543-553$.

25 Kurtz AB \& Nabarro JD. Circulating insulin-binding antibodies. Diabetologia $198019329-334$.

26 Lowell FC. Immunologic studies in insulin resistance. II. The presence of a neutralizing factor in the blood exhibiting some characteristics of an antibody. Journal of Clinical Investigation $194423233-240$.

27 Keilacker H, Rjasanowski I, Ziegler M, Michaelis D, Woltanski KP \& Besch W. Insulin antibodies in juvenile diabetes mellitus. Correlations to diabetic stability, insulin requirement and duration of insulin treatment. Hormone and Metabolic Research $198214227-232$.

28 Walford S, Allison SP \& Reeves WG. The effect of insulin antibodies on insulin dose and diabetic control. Diabetologia 1982 22 106-110.

29 Kurtzhals P, Schaffer L, Sorensen A, Kristensen C, Jonassen I, Schmid C \& Trub T. Correlations of receptor binding and metabolic and mitogenic potencies of insulin analogs designed for clinical use. Diabetes 200049 999-1005.

30 Drejer $\mathrm{K}$. The bioactivity of insulin analogues from in vitro receptor binding to in vivo glucose uptake. Diabetes Metabolism Reviews $19928259-285$

31 Chen JW, Ledet T, Orskov H, Jessen N, Lund S, Whittaker J, De Meyts P, Larsen MB, Christiansen JS \& Frystyk J. A highly sensitive and specific assay for determination of IGF-I bioactivity in human serum. American Journal of Physiology. Endocrinology and Metabolism 2003284 E1149-E1155.

32 Zendehdel K, Nyren O, Ostenson CG, Adami HO, Ekbom A \& Ye W. Cancer incidence in patients with type 1 diabetes mellitus: a population-based cohort study in Sweden. Journal of the National Cancer Institute 200395 1797-1800.

Received 9 February 2005

Accepted 1 September 2005 